\title{
Metaphorical terms in the context of linguistic research articles
}

\author{
Evgeniya Khabirova
}

DOI: 10.18355/XL.2018.11.02.40

\begin{abstract}
The article is devoted to the investigation of metaphorical terms in the context of research articles on linguistics. It considers the theoretical background of metaphorical conceptualization in the cognitive paradigm. The components of linguistic metalanguage are described in the paper. Metaphorical terms are considered not only as linguistic units, but also as units of professional knowledge or means of knowledge transfer. Metaphorical terms are viewed as idioms because of their figurativeness. The paper states that idioms are motivated by conceptual metaphors. The dictionary meaning of metaphorical terms is compared with contextual clues from research articles where they are used. The role of context in revealing the meaning of metaphorical terms is identified.
\end{abstract}

Key words: metaphorical term, metaphorical conceptualization, metaphor, context, linguistics

\section{Introduction}

This paper aims to reveal how the meaning of metaphorical terms in research articles on linguistics can be explicated in context.

Throughout its history, linguistics has been influenced by different linguistic traditions. In the process of cognition of linguistic phenomena, the main range of terms was formed, reflecting concepts and representations of the evolving sphere of knowledge. However, the problem of the development of the conceptual apparatus of linguistics constantly needs a special approach, scientific description, and comprehension (Nemyka, 2015: 23).

It is important to analyze the modern linguistic terminology system from the point of view of the evolution of a given layer of vocabulary, influenced by both internal and external factors, as well as the investigation and systematization of the metalanguage of linguistics, which makes it possible to consider all levels of language in dynamics. The need for such research arose due to the expansion of the terminology field of linguistics in relation to new trends in this field (Nemyka, 2015: 24).

Linguistic terminology appears to be a flexible system of terms reflecting all the recent progress and changes. Since new terms denote new concepts and phenomena in the sphere of linguistics, it is important to investigate the cognitive processes of term formation. Terms are now considered not only as linguistic units, but also as units of professional knowledge or means of knowledge transfer. Investigation of conceptual metaphor reveals the mechanisms of professional cognition.

One of the actively developed terminology processes are those of metaphorization, since metaphor is now regarded as a cognitive structure, which brings together mental representations and sentient experience. In cognitive linguistics, a metaphor is treated as a cognitive mechanism by which abstract concepts are interpreted in terms of more concrete ones.

The cognitive approach shows the significance of metaphorical conceptualisation in terminology (Meyer et al., 1997; Vandaele, 2002). Metaphorical conceptualisation is essential for framing ideas and naming abstract entities in specified language.

In cognitive linguistics, metaphorical terms are viewed as theory-constitutive metaphors (Boyd, (1979) 1998; Kuhn, (1979) 1998; Hoffman, 1980; Gibbs, (1994) 
1999). As Gibbs points out, theory-constitutive metaphors are essential parts of scientific theory ([1994] 1999: 172).

Modern research devoted to the cognitive basics of terminology and metaphorical terms (Golovanova, 2008; Dudeckaya, 2007; Zubkova, 2011; Mishankina, 2012; Mishlanova, 2002; Ovsyannikova, 2010; Sofronova \& Fel'de, 2011; Fel'de, 2011; Fel'de, 2012; Deeva, 2013; Glinskaya, 2013) demonstrate that metaphors are cognitive tools of term formation in different specified areas.

In his influential research on professional thinking, Schön (1993) identified metaphor as an indispensable component of understanding the frames professionals use in understanding problems. He advocated articulating and interpreting these metaphors, and using new metaphors for frame restructuring, or changing one's perspective on the nature of the problem.

Some of the earliest significant research devoted to metaphor as a cognitive mechanism is "Metaphors We Live by" By G. Lakoff and M. Johnson. They claim that "Metaphor is pervasive in everyday life, not just in language but in thought and action. Our ordinary conceptual system, in terms of we both think and act, is fundamentally metaphorical in nature" (Lakoff, 1980: 3).

Metaphorical expressions are described as the linguistic expressions of conceptual metaphors, while image metaphors are defined as metaphors resulting from the mapping of an image schema from a source domain onto the image schema from a target domain (Lakoff, 1987).

Being primarily concerned with figurative language, Evans considers a linguistic metaphor to be a metaphor, "that resides in (and emerges from) a situated (and hence contextualised) instance of language use" (Evans, 2010: 604).

Other studies argue against the distinction between literal and metaphoric interpretations, providing evidence for the increasing degrees of complexity of semantic integration. Thus, Coulson and Van Petten (2002) found the increase of amplitude as a function of metaphoricity, although the N400 of literal and metaphoric sentences was similar in quality. In addition, Giora (e.g., 2003, 2008) suggests the distinction between salient/non-salient expressions instead of literal/metaphoric ones. The processing of a particular meaning is determined by relative salience. The processing of idiomatic meanings is quicker than that of literal ones.

Davis (2011) points out that the meaning of an idiom does not result compositionally from the meanings of its components and its grammatical structure. He claims that, "As metaphors gradually die through repeated use, less and less attention is paid to the literal meaning. When dead, the formerly metaphorical meaning is conveyed directly, without conveying the literal meaning" (Davis, 2011: 2563).

According to J. A. Cuddon (1999: 412), idiom is "a form of expression, construction or phrase peculiar to a language and often possessing a meaning other than its grammatical or logical one".

According to Weinreich, "idiomaticity is important for this reason, if for no other, that there is so much of it in every language" (1969: 23).

Fillmore et al. claim that: "an idiomatic expression or construction is something a language user could fail to know while knowing everything else in the language" (Fillmore et al., 2003: 247).

Evans states that "while linguistic content includes highly schematic semantic knowledge, conceptual concept concerns richly detailed knowledge grounded in the information captured from multimodal brain states" (Evans, 2010: 614).

High density of figurative language along with terms, professionalisms, and items of professional jargon are typical feature of contemporary popular-scientific LSP texts. However, the use of figurative language units depends on the particular field (Ilinska et al., 2016: 257). 
Each professional sphere is full of its specialized lexical units reflecting the particular categories and concepts of professional reality. Altogether they form a range of linguistic means typical of this or that professional discourse.

Golovanova defines professional discourse as "verbally-mediated communication as a process of professional activity players-controlled interaction characterized by a certain set of rules, patterns of thinking and behaviour". The types of professional discourse may vary in discursive formats, as well as the dominant types (styles) of thinking (Golovanova, 2013: 32).

Kubryakova argues that "... in scientific texts, special attention is paid to the definition of introduced concepts and terms, the explanation of the categorical apparatus of the corresponding science, the logical omissions, narration violations are hardly possible" (Kubryakova, 2004: 513).

The terminology of Linguistics is also known as metalanguage. Representatives of different scientific schools abroad and in Russia create their own scientific "dialects", which sometimes claim the exclusive role of the general metalanguage of linguistics. However, since there are many schools, the terminology of linguistics, which is initially open, is artificially transformed into a number of relatively closed subsystems, which limits its functions, especially in professional communication and learning (Nemyka, 2015: 78).

According to Akhmanova, the subject of metalinguistics is the study of how people really speak when they are discussing certain objects of linguistic research, i.e. real metalanguage, which has the following main components:

1) proper terms, i.e. those words that are either not used at all in the object language or acquire a special meaning as they are borrowed from the object language;

2) peculiar combinations of words and their equivalents, leading to the formation of composite terms that characterize the metalanguage of linguistics already in its full form;

3) general scientific vocabulary (e.g., system, structure, class, category, etc.), which is a part of linguistic terminology, the obligatory linguistic component of its meaning is usually directly expressed by a compound term (language structure, language system, structure of the proposal, etc.);

4) nomenclature - a system of specific names that are used to denote specific linguistic objects (names and linguonyms);

5) a certain socio-linguistic aspect: this form of reaction reflects the specifics of one or another linguistic trend, epoch, etc. " (Akhmanova, 1990: 509).

Similarly, Leychik distinguishes the following groups of terms within the system: 1) the main terms in the terminology system, i.e. terms that denote the basic concepts of a certain sphere of knowledge or activity; 2) complex terms in the terminology system - terms denoting complex concepts (concepts that represent the logical product of the basic or derived concepts of a system of a particular area of knowledge or activity); 3) basic terms in the terminology system - terms denoting concepts borrowed in the system of concepts of a certain sphere of knowledge or activity from the system of concepts of the field that underlies (forms the basis) of this sphere of

knowledge or activity; 4) borrowed terms in the terminology - terms that denote concepts borrowed in the system of concepts of a certain sphere of knowledge or functioning from the system of concepts of the boundary sphere of knowledge, experience or activity (Leychik, 2009: 30).

In modern scientific discourse, one can observe a wide range of interdisciplinary terms-neologisms, representing concepts of a high degree of abstraction. Meanwhile, the terms-neologisms need to be defined within a scientific text, because they undergo the stages of development or formation (Nemyka, 2015: 59).

The context of discourse both constructs and constrains what is done with language, including the use of metaphor (Cameron, 1996).

XLinguae, Volume 11, Issue 2, April 2018, ISSN 1337-8384, eISSN 2453-711X 
"Discourse context is important because it helps both analysts and discourse participants to decide whether an utterance should be interpreted as metaphor." (Cameron, 2003: 5).

In fact, Kövecses and Szabó (1996) demonstrated that conceptual metaphors or other cognitive mechanisms motivate idiomatic expressions.

With relation to their cognitive function, conceptual metaphors have been divided into three types: a) structural metaphors, b) ontological metaphors and c) orientational metaphors (Kövecses, 2002: 32-33).

Briefly, structural metaphors are a way of understanding a typically abstract concept in terms of another typically concrete concept. An orientational metaphor has to do with concepts that are spatially related to each other through an upward-downward, inside-outside orientation, etc. Finally, the function of ontological metaphors is to represent an abstraction, such as an activity, emotion, or idea as something concrete, by assigning it a specific status like the status of an object, substance, or container, etc.

Kul'chitskaya identifies the following 4 groups of metaphors functioning in the text: metaphorical terms, general scientific expressions, metatext expressions, and the commonly used (recognized as undesirable) metaphorical words and combinations (Kul'chitskaya, 2013).

Faber states that, "terms not only represent specialized concepts, but also have syntax and collocational patterns within general language. In this sense, merely knowing terminological correspondences is hardly sufficient since such units, when inserted in an appropriate (or inappropriate) context, create ripples that affect the text at all levels" (Faber, 2009: 108).

To understand a text full of specialized language units it is important to know the domain, the concepts within it, the propositional relations within the text, as well as the conceptual relations between concepts within the domain (Faber, 2009: 121).

The main metaphorical models that are represented in numerous conventional and author metalanguage metaphorical expressions are analyzed by Mot'ko (2007) in her research "Metaphor in the metalanguage of Linguistics". The author distinguishes such models as anthropomorphic, nature-morphic, artifactual, and socio-morphic (Mot'ko, 2007: 11).

However, the comprehension of metaphorical terms in the context of research articles remains empirically under-researched.

\section{Methodology}

A reliable method for identifying metaphorically-used words in spoken and written language was invented by a group of metaphor scholars known as Pragglejaz Group (2007): "The procedure aims to establish, for each lexical unit in a stretch of discourse, whether its use in the particular context can be described as metaphorical" (Pragglejaz Group, 2007: 2). The "metaphor identification procedure" (MIP) implies establishing the meaning of a lexical unit in context. The lexical unit is considered metaphorical if its "contextual meaning contrasts with the basic meaning but can be understood in comparison with it" (Pragglejaz Group, 2007: 3).

The analysis of metaphoric meanings of specific terms suggested by Roldán-Riejos and Cuadrado (2015: 273) is based on frequency use, contextual clues, and specialised and general dictionaries. The procedure starts with hand-searching for metaphorical terms in specialized dictionaries based on informed intuition. Next, it is followed by definition and decomposition of the metaphorical terms into their semantic components. Finally, the analysis of the word origin accomplishes the procedure. The authors emphasize the importance of etymological analysis in order to avoid a possible over-interpretation of the terms as lexicalized metaphors when they were not. For the purpose of investigating the role of context in revealing the meaning of metaphorical terms in the linguistic discourse I made up a list of 205 metaphorical 
terms extracted from the specialized linguistic dictionaries. After that, a corpus of texts for the context analysis was gathered from the international academic journals on linguistics. All the articles under analysis are written in English. The journals are indexed in Scopus or Web of Science, which proves the high quality of the articles. The articles go through serious review and meet all the necessary requirements of the respected publications. I analyzed articles from the last 10 years (published from 2007 to 2017), as they are supposed to reflect the latest trends and problems of linguistics. The articles were chosen by keyword search containing the terms from the list.

The analysis process consisted of three steps. First, a list of metaphorical terms is formed from the entries of the specialized linguistic dictionaries. Second, research articles containing metaphorical terms are searched in the ScienceDirect and Web of Science databases. Third, the context of metaphorical terms is analyzed with reference to their dictionary meaning, i.e. if it includes any indications, explicating the meaning of a linguistic unit under analysis.

\section{Results}

According to the Routledge dictionary of language and linguistics a bridge verb is " $a$ term introduced by N.Erteschik in 1973 for verbs which allow extractions from finite complements" (1999: 145). This linguistic unit is a metaphorical term as it is formed by means of metaphorical conceptualization. The source domain for this term formation is a daily object (bridge) which is associated with the target domain of a scientific concept of a verb, allowing extractions from finite complements. The meaning of this term is not deduced from the meanings of its components. The context may help the reader to reveal the approximate meaning of the expression before looking it up in the dictionary.

A metaphorical term bridge verb is used in the article by Ambridge and Goldberg (2008) in a number of sentences in the following combinations: "semantically light verb of saying or thinking", "the complement clauses of bridge verbs", "bridge verbs which readily allow extraction", "only weakly backgrounding the complement clause", and "bridge verbs are most likely to allow extraction from their complement clause". Thus, the reader is able to guess from the context that a bridge verb is semantically light, it is related to saying or thinking, and allows extractions. In fact, in spite of the metaphoricity, the meaning of the term can be explicated from the context. Moreover, one element of the expression (verb) pertains to the linguistic terminology, whereas the other represents an ordinary object (bridge) which evokes and image of a link or connection in the reader's mind.

Another metaphorical term found in a linguistic dictionary is a cranberry morpheme. The meaning of the term has nothing to do with a berry. According to the Routledge dictionary of language and linguistics it denotes "a term referring to a bound morpheme which has no clear meaning or grammatical function, but which none the less distinguishes one word from another". The only function of the first element "cran" is to differentiate this word from other kinds of berries, such as blackberry, blueberry (1999: 500).

The term "cranberry morpheme" appears in the article by Arnold and Rahm (2014) in the following context:

"This refers to words that changed their spelling as it is in holiday (holy + day) as well as so-called cranberry morphemes, where the morpheme (resp. supposed modifier) occurs only once in a language and has (today) no specific meaning (examples include cranberry, cobwebs and lukewarm). These morphemes do not represent any words and can thus not be found in word lists or dictionaries."

Though the semantic structure of the above-mentioned term is not transparent, the context reveals one of the significant features of the morpheme - absence of specific meaning ("no specific meaning"), which correlates with the definition from the

XLinguae, Volume 11, Issue 2, April 2018, ISSN 1337-8384, eISSN 2453-711X 
dictionary ("no clear meaning"). As a result, the meaning of "a cranberry morpheme" becomes clearer from the context components.

A more complicated example of metaphorical conceptualization in linguistic terminology is a term "pied-piping", which is used to denote "the optional movement of a NP [noun phrase] or PP [prepositional phrase] containing the item which is affected by a movement rule, described by Ross. <... In a pied-piping construction, the whole phrase (NP) which includes the relative pronoun can be in initial position: the lady, pictures of whom I saw" (RDLL, 1999: 907).

The etymology of this metaphorical term goes back to 1967, when it was introduced by John Ross in his doctoral dissertation. "I am grateful to Robin Lakoff for suggesting this descriptive and picturesque terminology. Just as the children of Hamlin followed the Pied Piper out of town so the constituents of larger noun phrases follow the specified noun phrase when it is reordered"(Ross, 1967).

In order to decode the meaning of the term the reader should be acquainted with the fairy tale about the Pied Piper who was known for his luring children out of town by playing his flute. For a non-native English member of linguistic discourse community it would be quite difficult to interpret this term, because the analogical comparison of a phrase movement with a character from a fairy tale needs extralinguistic knowledge. The context of the article where the term "pied piping" is involved can shed some light onto its notion, though not giving complete understanding of the lexical unit. In the research article "Interrogative slifting in English" (Haddican et al. 2014) this term finds itself in such phrases, as, for example: "instances of embedded clause piedpiping", "Basque-type clausal pied-piping constructions", "complement clause piedpiping", "cases of finite clause pied-piping of the Basque type", "the pied-piped clause appears in the same left-peripheral position", "clausal pied-piping is derived from the same underlying structure that feeds long wh-movement", etc. It becomes clear from the context that "pied piping" is related to the position of clausal constructions and wh-movement to some extent, but the exact meaning of the term remains indistinct. This is due to the unique metaphorical comparison with a literary character which is far beyond the specialized sphere of Linguistics.

\section{Conclusion}

In conclusion, the results of the present study indicate that it is important for a linguist to obtain extralinguistic knowledge and develop language and metaphorical awareness in order to decode complicated metaphorical terms in linguistic research articles. Metaphorical conceptualization can be based on various analogical comparisons. If the source domain for metaphorization is taken from the daily sphere, the meaning of a metaphorical term can be easily revealed in the context. But if the source domain is taken from national culture or another professional field, extralinguistic knowledge is essential to explicate the target domain of a metaphorical term.

This study suggests interesting directions for further investigation of the cognitive specificity of term formation in the sphere of linguistics. Furthermore, the individual associations evoked by metaphorical terms can be studied regarding the level of education, experience, the sphere of scientific research and membership in the linguistics discourse society of the participants.

\section{Acknowledgements}

The work was supported by Act 211 Government of the Russian Federation, contract № 02.A03.21.0011.

\section{Bibliographic references}

AKHMANOVA O.S. 1990. Terminologiya lingvisticheskaya // Lingvisticheskiy entsiklopedicheskiy slovar' / pod red. V.N. Yartsevoy. M., 1990. p. 509. ISBN 585270-031-2. 
AMBRIDGE, B. - GOLDBERG, - ADELE E. 2008. The island status of clausal complements: Evidence in favor of an information structure explanation. In: Cognitive Linguistics, 19 - 3, pp.357 - 389. ISSN 0936-5907.

ARNOLD, P. - RAHM, E. 2014. Enriching ontology mappings with semantic relations. In: Data \& Knowledge Engineering, 93. pp. 1-18. ISSN: 0169-023X

BOYD, R. [1979] 1998. Metaphor and theory change: What is "metaphor" a metaphor for? In: Metaphor and Thought. Ortony, Andrew (ed.). Cambridge: Cambridge University Press. pp. 481 - 532. ISBN 0-521-40547-5.

CAMERON, L. 1996. Discourse context and the development of metaphor in children. In: Current Issues in Language and Society, 3, pp. 49 - 64. ISSN: 13520520

COULSON, S - VAN PETTEN, C. 2002. Conceptual integration and metaphor: An ERP study. Memory and Cognition, 30-6: pp. 958 - 968. ISSN: 0090-502X.

CUDDON, J. A. 1999. The Penguin Dictionary of Literary Terms and Literary

Theory. London: Penguin Books Ltd. ISBN: 978-0-14-051363-9.

DAVIS, W.A. 2011. 'Metalinguistic' negations, denial, and idioms. In: Journal of Pragmatics, 43 - 10. pp. 2548-2577. ISSN: 0378-2166.

DEEVA, A.I. 2013. Asimmetrichnost' angliyskoy i russkoi terminosistem v aspekte metaforicheskogo modelirovaniya. Tomsk: Contemporary problems of literature studies and linguistics. Conference of young scientists' proceedings, issue 14, Vol.1. Linguistics (pp. 30-34). Tomsk: State University Publ. [Asymmetry of the English and Russian terminological systems in the aspect of metaphorical modeling]. (Rus.)

DUDECKAJA, S. G. 2007 Metaforizacija kak sposob terminoobrazovanija : na materiale anglijskoj terminologii cherepno-cheljustno-licevoj hirurgii i stomatologii : dis. ... kand. filol. nauk / S. G. Dudeckaja. - Samara, 2007.

EVANS, Vyvyan, 2010. Figurative Language Understanding in LCCM Theory. In: Cognitive Linguistics, 21 - 4. pp. 601-662. ISSN: 0936-5907.

FABER BENITEZ, P. 2009. The Cognitive Shift in Terminology and Specialized Translation. In: MonTI: Monografías de Traducción e Interpretación, (1) pp. 107-134. ISSN 1889-4178.

FEL'DE, O.V. 2011. Komicheskoe v professional'nom diskurse. Novosibirsk: Novosibirsk State University Scientific Journal Vestnik, vol.11, issue 9: Philology, 140-145. [Comical in professional discourse]. (Rus.) ISSN: 1818-7919.

FEL'DE, O.V. 2012. Leksika professional'nogo substrata v leksikograficheskom osveshchenii. Novosibirsk: Novosibirsk State University Scientific Journal Vestnik. History, Philology, vol.11, issue 9. Philology, 41-46. [Lexis of the professional substrate from lexicographic perspective]. (Rus.) ISSN: 1818-7919.

FILLMORE, Ch. J. - KAY, P. - O'CONNOR, M. C. 2003. "Regularity and Idiomaticity in Grammatical Constructions: The Case of Let Alone", In: Tomasello, M. (Ed.). The New Psychology of Language. Cognitive and Functional Approaches to Language Structure. vol. 2. Mahwah, New Jersey, London: Lawrence Erlbaum Associates, Publishers, pp. 243-270. ISBN: 0-8058-3428-1.

GIBBS, Raymond W. [1994] 1999. The Poetics of Mind: Figurative Thought, Language and Understanding. Cambridge: Cambridge University Press. ISBN: 0-52141965-4

GIORA, Rachel. 2003. On our mind: Salience, context, and figurative language. New York: Oxford University Press. ISBN: 0-19-513616-0.

GIORA, Rachel. 2008. Is metaphor unique? In: R. Gibbs (ed.), The Cambridge handbook of metaphor and thought, pp. 143-160. Cambridge: Cambridge University Press. ISBN: 0521841062.

GLINSKAYA, N.P. 2013. Problema ekvivalentnosti perevoda otreaslevoi terninologii (na materiale amerikanskogo avtorskogo prava). Moscow: MSU Philological sciences. Theoretical and practical questions, 6 (1), pp. 56-69. [The problem of

XLinguae, Volume 11, Issue 2, April 2018, ISSN 1337-8384, eISSN 2453-711X 
translation equivalence of a branch terminology (as exemplified in American authors' rights terminology)]. (Rus.) ISSN: 1997-2911

GOLOVANOVA, E. I. 2008 Kognitivnoe terminovedenie [Cognitive terminology]. Chelyabinsk, Encyclopedia. 180 p. ISBN: 978-5-91274-043-5

GOLOVANOVA, E. I. 2013. Professional'nyj diskurs, subdiskurs, zhanr professional'noj kommunikacii: sootnoshenie ponjatij [Professional discourse, subdiscourse, genres of professional communication: concepts relation]. Vestnik Cheljabinskogo gosudarstvennogo universiteta [Bulletin of Chelyabinsk state university], 1(292), pp. 32-35. ISSN: 1994-2796

HOFFMAN, Robert R. 1980. Metaphor in science. In: Cognition and Figurative Language. Honeck, Richard P.; Hoffman, Robert R. (eds). Hillsdale, N.J.: Lawrence Erlbaum Associates. Pp. 393-423. ISBN: 0898590477

ILINSKA, L. - PLATONOVA, M. - SMIRNOVA, T. 2016. Metaphorical Competence in Professional Communication / Procedia - Social and Behavioral Sciences 236. pp. 254 - 259. ISSN 1877-0428

KÖVECSES, Z. 2002. Metaphor: A Practical Introduction. New York: Oxford University Press. ISBN: 0-19-514510-0.

KÖVECSES, Z. - SZAB'O, P. 1996. Idioms: A view from cognitive semantics. Applied Linguistics, 17 (3). pp. 326-355. ISSN: 0142-6001 CAMERON, L. 2003. Metaphor in educational Discourse. London, New York: Continuum. ISBN: 0-8264-4939-5.

KUBRYAKOVA, E. S. 2004. Jazyk i znanie [Language and knowledge]. Moscow: Jazyki slavjanskoj kul'tury. ISBN : 5-944457-174-8.

KUHN, Thomas S. [1979] 1998. Metaphor in science. In: Metaphor and Thought. Ortony, Andrew (ed.). Cambridge: Cambridge University Press. 533-542. ISBN: 9781139173865.

KUL'CHITSKAYA L. V. 2013. Kontseptual'naya metafora i obuchenie yazyku lingvisticheskoy teorii perevoda // Vestnik MGLU. №9 (669). Available online: http://cyberleninka.ru/article/n/kontseptualnaya-metafora-i-obuchenie-yazyku-

lingvisticheskoy-teorii-perevoda ISSN: 2542-2197

LAKOFF, G.1987. Image metaphors. In: Metaphor and symbolic activity, II: 3, pp. 219-222. ISSN: 1532-7868.

LAKOFF, G. - JOHNSON, M. 1980. Metaphors, We Live by. Chicago: University of Chicago Press. ISBN: 0-226-46801-1.

LEYCHIK, V.M. 2009. Terminovedenie. Predmet, metody, struktura. Moskva. ISBN 978-5-397-00486-2

MEYER, I. - ZALUSKI, V. - MACKINTOSH, K. 1997. Metaphorical Internet terms: A conceptual and structural analysis. In: Terminology 4 (1). pp. 31-33. ISSN: 0929-9971.

MISHANKINA N. A. 2012. Metafora v terminologicheskikh sistemakh: funktsii i modeli [Metaphor in terminological systems: functions and models]. Tomsk, Bulletin of the Tomsk State Univeristy, № 4 (20). pp. 32-45. ISSN: 1998-6645

MISHLANOVA S. L. 2002. Metafora v meditsinskom diskurse [Metaphor in medical discourse]. Perm'. 160 p. ISBN 5-8241-0304-6

MOT'KO, M.L. Metafora v metayazyke lingvistiki (na materiale angliyskogo yazyka) Avtoreferat dissertatsii na soiskanie uchenoy stepeni kandidata filologicheskikh nauk Barnaul-2007. $23 \mathrm{~s}$.

NEMYKA, A.A. 2015. Metayazyk lingvistiki: nauchnoe i khudozhestvennoe predstavlenie. Diss. Dokt. Filol. Nauk.

OVSYANNIKOVA, V.V. 2010. Metaforicheskie modeli v nauchnom geologicheskom diskurse. Tomsk. Author's abstract. [Metaphorical models in scientific geological discourse]. (Rus.)

PRAGGLEJAZ GROUP. 2007. MIP: A Method for Identifying Metaphorically Used Words in Discourse. In: Metaphor and Symbol, 22(1). pp. 1-39. ISSN: 10926488. 
RDLL - BUSSMANN, Hadumod. 1999. Routledge dictionary of language and linguistics. - Routledge. 560 p. ISBN: 0-203-98005-0.

ROLDAN-RIEJOS, A. - CUADRADO, G. 2015. Metaphor and Figurative Meaning Construction in Science and Technology (English and Spanish). In: Procedia - Social and Behavioral Sciences, 212. pp. 271 - 277. ISSN: 1877-0428

ROSS, J. R. 1967. Constraints on Variables in Syntax. Doctoral dissertation, MIT. [Published in 1986 as Infinite Syntax. Norwood, N.J.: ABLEX.] Excerpted in Gilbert Harman (ed.), On Noam Chomsky - Critical Essays. pp. 165--200. Anchor Press/Doubleday. 1974, Available online: http://lingo.stanford.edu/sag/L222B/papers/ross-excerpts.pdf

SCHON, D. A. 1993. Generative metaphor: A perspective on problem-setting in social policy. In A. Ortony (Ed.), Metaphor and thought. pp. 137-163. Cambridge, UK: Cambridge University Press. ISBN: 9781139173865. Available online: http://dx.doi.org/10.1017/cbo9781139173865.011

SOFRONOVA, T.M. - FEL'DE, O.V. 2011. Prototip dvuyazychnogo elektronnogo glossariya pirologicheskoy terminologii. In: Vestnik Tomskogo gosudarstvennogo universiteta, 345. pp.38-43. [Prototype of bilingual electronic glossary of fire science terminology]. (Rus.) ISSN: 1561-7793

VANDAELE, S. 2002. Metaphorical Conceptualization in Cell Biology. In: Proceedings of the Tenth EURALEX International Congress II. Braasch, Anna; Povlsen, Claus (eds). Copenhagen: Center for Sprogteknologie. pp. 649-655. ISBN: 87-90708-09-1

WEINREICH, U. 1969. "Problems in the Analysis of Idioms", In: Puhvel, J. (Ed.). Substance and Structure of Language. Berkeley \& Los Angeles: University of California Press. pp. 23-81.

ZUBKOVA O. S. 2011. Lingvosemiotika professional'noy metafory [Lingvosemiotics of professional metaphor]. Kursk.

Words: 4521

Characters: 31787 (17,66 standard pages)

Assoc. prof., Candidate of Philological Sciences

Evgeniya Igorevna Khabirova

Department of Foreign Languages

Institute of Linguistics and International Communication

South Ural State University

76, Lenin Prospekt, 454080 Chelyabinsk

Russia

khabirovaei@susu.ru

XLinguae, Volume 11, Issue 2, April 2018, ISSN 1337-8384, eISSN 2453-711X 